\title{
Peranan Aparat Dalam Pelayanan E-KTP di Kantor Kecamatan Kaledupa Kabupaten Wakatobi
}

\author{
Kariadin', Mansur², Wa Ode Wati Nurbaena ${ }^{3}$ \\ ${ }^{1}$ Mahasiswa FISIP UM. Buton \\ 2Dosen FISIP UM. Buton \\ ${ }^{3}$ ASN BKKBN Kota Baubau
}

\begin{abstract}
Abstrak, Pemberlakuan E-KTP oleh pemerintah sebagai wujud reformasi dan penataan administrasi kependudukan, hanya saja E-KTP masih belum maksimal terutama dalam penyalurannya yang belum menjangkau keseluruhan populasi penduduk. Penelitian ini bertujuan untuk mengkaji peran aparat dalam pelayanan E-KTP di Kantor Kecamatan Kaledupa. Jenis penelitian kualitatif dengan tipe deskriptif, sampel menggunakan pusposive sampling. Pengumpulan data dilakukan dengan melakukan wawancara, observasi dan telaah dokumen. Data kemudian dianalisis secara interaktif dan disajikan dalam bentuk deskriptif. Penelitian ini menjelaskan bahwa pelayanan E-KTP di Kantor Kecamatan Kaledupa berjalan optimal, pelayanan dilakukan dengan baik, penyampaian informasi yang jelas hingga pemberian layanan lainnya berlansung dengan baik. Hal ini dapat diukur melalui peran aparat menurut indikator daya tanggap (responsivenees), Kehandalan (Reability), Kompetensi (competence), Jaminan (assurance), Empati (emphaty) dan Akses (access). Hanya saja sarana dan prasarana yang terbatas dan operator yang tidak seimbang dengan jumlah masyarakat yang akan dilayani seringkali membuat pelayanan menjadi lambat dan tidak efektif.
\end{abstract}

Kata Kunci: Peranan, Pelayanan, E-KTP, Wakatobi

\begin{abstract}
The implementation of E-KTP by the government as a form of reform and structuring population administration, only E-KTP is still not optimal, especially in the distribution that has not reached the entire population. This study aims to examine the role of officials in E-KTP services in the Kaledupa District Office. Type of qualitative research with descriptive type, sample uses purposive sampling. Data collection is done by conducting interviews, observation and document review. Data is then analyzed interactively and presented in descriptive form. This study explains that the E-KTP service in the Kaledupa District Office runs optimally, the service is done well, the delivery of clear information so that the provision of other services takes place properly. This can be measured through the role of officials according to indicators of responsivenees, reliability, competence, assurance, empathy and access. It's just that limited facilities and infrastructure and operators that are not balanced with the number of people to be served often make services slow and ineffective.
\end{abstract}

Keywords: Role, Service, E-KTP, Wakatobi 


\section{Pedahuluan}

Tuntutan publik atas sebuah pelayanan publik memaksa pelayanan harus selalu berorientasi pada masyarakat atau pelanggan yang dilayani. Hal ini berimplikasi terhadap kemampuan aparatur dalam melaksanakan tugas tersebut. Diatas kertas mungkin saat ini sistem pemerintahan kita memiliki rangkaian yang jelas dalam memberikan pelayanan yang biasa disebut pelayanan prima tersebut. Sebagai daerah Otonomi Baru, Kabupaten Wakatobi memerlukan pelayanan publik yang bukan saja mampu memberikan kepastian kepada masyarakat, namun juga mampu mendukung pembangunan daerah.

Hakikat pelayanan publik adalah pemberian pelayanan prima kepada masyarakat yang merupakan perwujudan kewajiban aparatur pemerintah sebagai abdi masyarakat. Karena itu pengembangan kinerja pelayanan publik senantiasa menyangkut tiga unsur pokok pelayanan publik, yakni: unsur kelembagaan penyelenggara pelayanan, proses pelayanannya serta sumber daya manusia pemberi layanan. Dalam hubungan ini maka upaya peningkatan kinerja pelayanan publik senantiasa berkenan dengan pengembangan tiga unsur pokok tersebut. Dalam era globalisasi sekarang ini pemerintah telah merancangkan dan menjalankan program nasional administrasi kependudukan yaitu dalam bentuk eKTP dalam rangka Implementasi Undang-Undang Nomor 23 Tahun 2006 Tentang Administrasi Kependudukan dan Peraturan Presiden Nomor Nomor 26 Tahun 2009 Pasal 10 tentang Penerapan KTP Elektronik (e-KTP).

Implementasi penggunaan e-KTP menemui beberapa kendala dalam pelaksanaanya, hal ini telah terlihat sejak awal pelaksanaan program ini dimulai. Sebagai fokus penelitian ini yang terjadi di Kecamatan Kaledupa Kabupaten Wakatobi. Secara umum di Kabupaten Wakatobi proses pembuatan e-KTP masih diperhadapkan oleh adanya peralatan yang terbatas, jumlah operator kecamatan serta sarana dan prasarana penunjang lainnya (rakyatsultra, 2014). Dalam hal pendistribusian,masyarakat sering mengkomplain karena ketika pembuatan e-KTP dilakukan bersamaan namun pada saat pendistribusian ada yang sudah mendapatkan dan ada yang belum. Hingga triwulan pertama tahun 2015 di Kecamatan kaledupa yang penulis himpun dari berbagai sumber, data capaian keberhasilan penyelesaian 
dan penyaluran e-KTP masih belum maksimal karena dari sekitar 6.212 orang yang memenuhi syarat umur eKTP, namun baru terdapat sekitar 3.391 e-KTP yang sudah tersalur sampai saat ini atau hanya sekitar 54,6 \% yang telah selesai dan tersalur di Masyarakat Kecamatan Kaledupa. Dapat dikatakan produktifitas dari pelayanan e-KTP sangat rendah. Masih banyak masyarakat yang telah menyelesaikan administrasi untuk pembuatan e-KTP, sudah mengisi data sidik jari sampai dengan rekam tanda tangan untuk pembuatannya namun sampai sekarang belum menerima E-KTP dan pemerintahan kecamatan pun belum bisa memastikan kapan akan selesainya. Penyebabnya mulai dari kurangnya alat rekam dan koneksi internet yang belum optimal (rakyatsultra,2015) hingga kinerja aparat pemerintah mulai dari kelurahan hingga kecamatan yang belum maksimal pengoperasian sarana dan prasarana (wakatobi.go.id, 2015).

Dalam perspektif lainnya, penulis mengamati fenomena ini dilapangan dan dikomparasikan dengan beberapa pendapat masyarakat, terjadinya berbagai persoalan dalam pembuatan eKTP lebih didominasi oleh ketidakmengertian masyarakat baik dalam proses pembuatan e-KTP hingga kegunaanya. Oleh karena itu, penelitian ini didasarkan oleh pendapat bahwa perlu adanya kajian mengenai peran Aparat dalam melakukan layanan pembuatan e-KTP di tingkat kecamatan.

\section{Metode Penelitian}

Jenis penelitian ini adalah kualitatif dengan tipe penelitian deskriptif yang bermaksud untuk memberikan uraian mengenai suatu gejala social yang diteliti, penelitian ini dilakukan dengan cara deskriptif kualitatif yakni berusaha mendeskripsi kualitas suatu gejala yang menggunakan ukuran urusan sebagai dasar penilaian (Slamet, 2006: 7). Disamping itu penelitian deskriptif menggunakan metode survey (Atherton \& Klemmack, 1982; dalam Soehartono, 2008: 35) yaitu dengan mengumpulkan dan menganalisis suatu peristiwa atau proses tertentu dengan memilih data atau menentukan ruang lingkup tertentu sebagai sampel yang dianggap representatif.

\section{Hasil Penelitian}

1. Karakteristik Aparat

\section{Kecamatan Kaledupa}

Karakteristik aparat sengaja diangkat dalam penelitian ini karena 
dengan mengetahui karakteristik serta identitas aparat yang nantinya bakal menjadi obyek penelitian, tentunya akan mempermudah dalam menyelesaikan masalah-masalah yang nantinya peneliti angkat didalam penelitian yang dijalankan.

Secara keseluruhan jumlah aparat pemerintah kecamatan Kaledupa berjumlah 27 orang. Jumlah ini adalah jumlah dari keseluruhan aparat organik (PNS) dan tenaga honorer (magang), dengan rincian 20 orang adalah pegawai negeri sipil (PNS) dan 7 Orang adalah tenaga honorer (magang) atau bisa dilihat pada table 4.3. Dengan rincian menurut jenis kelamin adalah 12 orang berjenis kelamin laki-laki dan 15 orang berjenis kelamin perempuan.

Dari sisi usia, menurut data yang didapati dalam observasi lapangan menyatakan bahwa aparat di Kantor Kecamatan Kaledupa di dominasi oleh mereka yang berusia masih relatif muda. Dengan melihat komposisi umur yang ada maka sangat diperlukan adanya pembinaan dan pengembangan Sumber Daya Manusia (SDM) yang baik dari pemerintah agar dapat meningkatkan kinerja dari aparat. Tingkat pendidikan memiliki kaitan dengan tingkat kemampuan aparat dalam melaksanakan tugas dan pekerjaan yang diberikan. Hal ini didasarkan pada asumsi bahwa aparat pemerintah yang memiliki pendidikan yang tinggi akan mampu memahami dan menjawab persoalan tugas dan pekerjaaan yang dihadapi sehingga dapat meningkatkan kinerja mereka.

\section{Peran Aparat Dalam Pelayanan KTP di Kecamatan Kaledupa}

Pelayanan publik adalah bagian paling esensial dalam fungsi-fungsi yang dijalankan oleh pemerintahan. Disisi lain, perkembangan suatu pemerintahan baik pusat maupun daerah dapat dilihat dari kualitas pelayanan publiknya. Dalam penelitian ini mengkaji peran aparatur pemerintah kantor kecamatan kaledupa dalam pelayanan pembuatan e-KTP.

Salah satu pendekatan yang digunakan untuk mengukur peran aparatur adalah pendekatan efektivitas pelayanan public melalui persepsi pegawai dan masyarakat yang dilayani. Tinggi rendahnya peran aparatur tergantung pada bagaimana pelanggan merasakan pelayanan yang nyata sesuai dengan yang mereka harapkan. Karena kualitas mengacu pada segala sesuatu yang menentukan kepuasan pelanggan maka suatu produk (Jasa) yang 
dihasilkan baru dapat dikatakan berkualitas apabila sesuai dengan harapan atau keinginan pelanggan.

Termasuk dalam pelayanan pembuatan e-KTP yang merupakan program pemerintah dalam penataan administrasi kependudukan. Secara nasional pemberlakuan e-KTP diawali dengan pengurusan e-KTP di tingkat kecamatan masing-masing daerah. Posisi kecamatan dalam proses pelayanan e-KTP adalah untuk melakukan perekaman data penduduk, dimana pada tiap kecamatan dibekali peralatan untuk itu dan operator kecamatan, untuk selanjutnya dalam penerbitan blanko e-KTP oleh Pemerintah Pusat melalu Dinas Kependudukan dan Catatan Sipil Kota/ Kabupaten.

Adapun dasar hukum diberlakukannya e-KTP adalah sebagai berikut :

a. Undang-Undang No. 23 Tahun 2006 tentang Administrasi Kependudukan.

b. Peraturan Pemerintah No. 37 Tahun 2007 tentang pelaksanaan UU No.23 Tahun 2006 tentang Administrasi Kependudukan c. Peraturan Pemerintah Nomor 96 Tahun 2015 Tentang Pelayanan Umum

d. PERPRES No 25 Tahun 2008 Tentang tatacara Persyaratan Pendaftaran Penduduk dan Pencatatan Sipil.

e. PERPRES No 26 Tahun 2009 Tentang Penerapan KTP Berbasis NIK Secara Nasional

f. PERPRES No 35 Tahun 2010 Tentang Perubahan Atas PERPRES No 26 Tahun 2009 Penerapan E-KTP Paling Lambat Tahun 2012.

Pada saat ini pemerintah menetapkan kebijakan mengenai administrasi kependudukan berdasarkan UndangUndang Nomor 23 Tahun 2006 tentang Administrasi Kependudukan. Melalui Kemendagri saat ini sedang melaksanakan program e-KTP berbasis Nomor Induk Kependudukan (NIK) sebagai pelaksanaan Undang-Undang Nomor 23 Tahun 2006 Tentang Administrasi Kependudukan. Pelayanan e-KTP dikoordinasi di Kecamatan masing-masing. Untuk proses pengambilan foto dan sidik jari dilakukan Kantor Kecamatan melalui surat pemanggilan yang disalurkan 
melalui kantor kelurahan/ desa masingmasing.

\section{Pembahasan}

Dari penjelasan tersebut, dan beberapa kali observasi yang dilakukan oleh peneliti melihat bahwa proses pelayanan e-KTP tidak begitu jauh berbeda dengan penyelenggaraan pelayanan tingkat kecamatan secara umum. Sekalipun kemudian saat ini penyelenggaraan pelayanan e-KTP dilakukan di Dinas Kependudukan dan Catatan Sipil, namun posisi kecamatan dalam proses awalnya kecamatan mempunyai kewenangan untuk melayani pembuatan e-KTP. Maka penelitian ini disusun untuk kemudian memahami dan mengkaji peran yang dilakukan pegawai kecamatan kaledupa dalam proses pelayanan khususnya pelayanan e-KTP bagi masyarakat Kaledupa. Data diperoleh melalui sumber wawancara serta didukung oleh data yang terkait dengan proses pelayanan e-KTP yang berlangsung di Kantor Kecamatan Kaledupa.

Penilaian kinerja terhadap pelayanan publik khususnya pelayanan e-KTP, tidak cukup hanya dilakukan dengan menggunakan indikatorindikator yang melekat pada pengguna jasa, seperti efisiensi dan efektifitas, tetapi juga harus dilihat dari indikatorindikator yang melekat pada penyedia jasa dalam hal ini adalah pegawai lingkup Kantor Kecamatan Kaledupa, yaitu :

\section{Daya Tanggap Aparat} (Responsiveness)

Daya tanggap (responsiveness) dimaksudkan yaitu kemauan atau keinginan para pegawai untuk membantu dan memberikan jasa yang dibutuhkan oleh masyarakat. Ketanggapan pegawai merupakan bagian dari dimensi mutu pelayanan pada khususnya tanggap didalam melayani masyarakat. Daya tanggap pegawai tentu akan mempengaruhi kepuasan masyarakat dalam proses pelayanan public di kecamatan.

Berdasarkan hasil penelitian dan wawancara yang dilakukan yang berkaitan dengan responsivitas, yaitu kemampuan untuk membantu pemohon (masyarakat) berupa informasi atau memberikan pelayanan dengan cepat dan tanggap pada dasarnya sudah dilaksanakan cukup baik oleh para pegawai Kecamatan Kaledupa, terbukti dengan adanya sosialisasi yang dilakukan pihak Kantor Kecamatan. 
Kecepatan dalam pemberian pelayanan kepada masyarakat sangat diperlukan untuk meningkatkan efisiensi dalam administrasi mengingat kegagalan dalam melaksanakan disiplin kerja dipengaruhi oleh karena kurang profesionalnya atasan dalam melaksanakan tugas sehingga tidak perlu dipersalahkan jika masyarakat dalam menerima pelayanan senantiasa ada keluhan dan kritikan yang diterimanya. Hal itu merupakan salah satu dari kurangnya birokrat-birokrat yang mampu memberikan pelavanan yang memuaskan kepada masyarakat. Sekalipun secara umum daya tanggap terhadap pemberian layanan oleh aparat kecamatan sudah optimal, namun tetapi dalam memberikan pelayanan tersebut perlu ditingkatkan lagi kualitasnya.

proses layanan berlangsung optimal, namun dalam beberapa kali pengamatan langsung penulis menemukan bahwa seringkali pelayanan menjadi begitu lama dan memakan waktu yang cukup panjang, disebabkan oleh karena keterbatasan sarana dan prasarana dan kemampuan mengoperasikannya. Misalnya pengoperasian komputer, yang pada akhirnya menunggu aparat yang bisa menggunakannya datang ke kantor.
Namun pada dasarnya, keinginan untuk memberikan pelayanan yang cepat dan berkualitas tetap ada, hanya saja dalam penggunaan sarana dan prasarana yang kadang membuat suatu layanan menjadi lambat dan kurang efektif.

\section{Kehandalan (realiability)}

Kehandalan (Reliability), yaitu kemampuan untuk memberikan pelayanan yang dijanjikan dengan tepat (accurately) dan kemampuan untuk di percaya (dependably) terutama memberikan jasa secara tepat waktu (ontime), dengan cara yang sama sesuai dengan jadwal yang telah dijanjikan dan tanpa melakukan kesalahan setiap kali berlangsungnya pelayanan.

Kehandalan adalah unsur pelayanan yang dapat dilihat dari kemampuan untuk melaksanakan pelayanan jasa yang dijanjikan dengan tepat dan ter percaya. Reability dalam pelayanan pembuatan e-KTP di Kecamatan Kaledupa meliputi kesederhanaan, kejelasan, dan kepastian mengenai prosedur, biaya, serta kesesuaian pelayanan dengan informasi yang diberikan, sehingga pemohon merasa puas dengan pelayanan yang mereka terima. Kesederhanaan, 
kejelasan prosedur pelayanan juga menjadi indikator kualitas pelayanan.

Memang kendala yang ditemukan dari hasil wawancara tersebut diatas menjadi salah satu kendala aparat kecamatan untuk memberikan kepastian kepada masyarakat. Maka dapat disimpulkan pada posisi ini bahwa peran aparat Kecamatan Kaledupa berkenaan dengan memberikan pelayanan yang dijanjikan dengan tepat (accurately) dan kemampuan untuk di percaya (dependably) terutama memberikan jasa secara tepat waktu (ontime), sesuai dengan jadwal yang telah dijanjikan dan tanpa melakukan kesalahan setiap kali, kepastian mengenai prosedur, biaya, serta kesesuaian pelayanan dengan informasi yang diberikan dapat disimpulkan bahwa pelayanannya belum berjalan dengan baik.

Disisi lain, Kesederhanaan, kejelasan prosedur pelayanan juga menjadi indikator kualitas pelayanan. Pelayanan publik yang baik harus mempunyai prosedur pelayanan yang sederhana dan jelas, sehingga dapat dipahami dan dilaksanakan dengan mudah oleh pengguna jasa.

\section{Kompetensi (competence)}

Competence/kompetensi, artinya setiap orang dalam suatu organisasi memiliki keterampilan dan pengetahuan yang dibutuhkan agar dapat memberikan pelayanan tertentu. Kemampuan pegawai adalah salah satu faktor penyebab baik atau buruknya suatu pelayanan. Kompetensi adalah bagian dari kepribadian yang mendalam dan melekat kepada seseorang serta perilaku yang dapat diprediksi pada berbagai keadaan dan tugas pekerjaan.

Pengurusan e-KTP ditingkat kecamatan memang disertai dengan operator alat perekaman data penduduk, yang sebelumnya sudah di beri pelatihan untuk mengoperasikan alat. Hanya saja, jumlah operator yang hanya dua orang dengan rasio masyarakat yang harus dilayani sekitar 6.212 orang, adalah cukup timpang. Belum lagi diperhadapkan jika kemudian alat yang digunakan rusak atau tidak berjalan optimal, maka pelayanan akan terhambat dan sudah pasti tidak berjalan optimal. Kekurangan kompetensi aparat lainnya menjadikan kendala ini menjadi masalah yang perlu diperhatikan dalam pelayanan.

Selain itu juga, waktu penyelesaian sebuah pelayanan 
merupakan elemen yang sangat penting dalam menjamin kepuasan pengguna jasa mengingat tidak semua masyarakat mempunyai banyak waktu. Terkait dengan pengetahuan mengenai standar lama waktu proses penyelesaian pelayanan e-KTP ternyata juga tidak banyak diketahui oleh informan. Namun, secara umum persepsi mereka tentang lama waktu proses pelayanan e-KTP dirasakan telah cukup cepat.

Kinerja birokrasi publik tidak hanya bisa dilihat dari ukuran internal yang dikembangkan oleh birokrasi publik atau pemerintah, seperti pencapaian target.Kinerja sebaiknya harus dilihat dari ukuran eksternal, seperti nilai-nilai dan norma-norma yang berlaku di masyarakat. Suatu kegiatan birokrasi publik memiliki akuntabilitas yang tinggi kalau kegiatan itu dianggap benar dan sesuai dengan nilai-nilai dan norma yang berkembang dalam masyarakat.

\section{Jaminan (assurance)}

Assurance (jaminan), yaitu meliputi pengetahuan, kemampuan, keramahan, sopan, dan sifat dapat dipercaya dari kontak personel untuk menghilangkan sifat keraguan konsumen dan merasa terbebas dari bahaya dan resiko. Jaminan merupakan faktor yang sangat penting yang harus benar-benar diperhatikan oleh penyedia layanan, dalam hal ini Kantor Kecamatan Kaledupa, dengan adanya jaminan yang pasti pemohon administrasi kependudukan dan pencatatan sipil akan percaya dengan kemampuan yang diberikan pihak instansi, sehingga mereka merasa puas.

Dalam pengamatan langsung peneliti menemukan bahwa, peran aparat kecamtana dalam pelayanan eKTP sudah sesuai dengan aturan yang berlaku karena ini merupakan program nasional yang didasarkan pada Peraturan Presiden Nomor 26 tahun 2009 tentang Penerapan KTP Berbasis NIK secara Nasional sebagaimana telah diubah dengan Peraturan Presiden Nomor 35 Tahun 2010 yang di berlakukan dan berlaku wajib bagi setiap warga Negara Indonesia. Dapat dilihat karena tidak ada yang dipersuli dan kegiatan ini juga berlangsung dengan waktu yang tidak lama, akan tetapi ada beberapa hal yang harus diperhatikan karena sudah seperti luput dari pengawasan aparat seperti waktu penyelesaian e-KTP yang lama sekali, serta petugas tidak mengingatkan kembali untuk aktivasi e-KTP. Hampir semua penduduk yang telah memiliki e- 
KTP belum mengaktifasikannya bukan karena sengaja tetapi mereka tidak mengetahuinya

\section{Empati (emphaty)}

Emphaty (empati), adalah keseriusan dan ketulusan dalam melayani masyarakat, sikap tegas tapi penuh perhatian terhadap masyarakat, sehingga memudahkan dalam melakukan hubungan komunikasi yang baik dan memahami kebutuhan dan keinginan masyaraka dalam mendapatkan pelayanan. Empati adalah suatu proses ketika seseorang merasakan perasaan orang lain dan menangkap arti perasaan itu, kemudian mengkomunikasikannya dengan kepekaan sedemikian rupa hingga menunjukkan bahwa ia sungguhsungguh mengerti perasaan orang lain itu.

Mengenai empati dalam pelayanan publik secara umum adalah bagian dari visi dan misi Kabupaten Waktobi, yang berusaha menciptakan pelayanan public yang berkualitas guna mendukung visi dan misi Kabupaten Wakatobi.

Berdasarkan hasil penelitian dan wawancara yang dilakukan di Kantor Camat Kaledupa berkaitan dengan Emphaty (empati), yaitu keseriusan dan ketulusan dalam melayani masyarakat, sikap tegas tapi penuh perhatian terhadap masyarakat, sehingga memudahkan dalam melakukan hubungan komunikasi yang baik dan memahami kebutuhan dan keinginan masyarakat dalam mendapatkan pelayanan sudah cukup baik dilaksanakan oleh petugas e-KTP hanya saja kendalanya ada dipenguasaan alat alat dan sarana dan prasarana yang ada.

Dari penggambaran diatas, dapat dipahami bahwa empati yaitu usaha dari pihak penyedia layanan untuk mengenal dan memahami kebutuhan pelanggan dan menaruh perhatian pada mereka secara individual. Bentuk perhatian ini juga meliputi penciptaan rasa puas dan berusaha untuk memahami apa yang diperlukan oleh para pengguna jasa atau pemohon E-KTP. Bentuk empati dalam pelayanan juga dapat diwujudkan dengan berusaha membantu dalam memecahkan suatu masalah secara spontan dan senang hati.

\section{Akses (access)}

Access/akses, meliputi kemudahan untuk dihubungi dan ditemui. Sesuai dengan reformasi birokrasi Indonesia bertujuan untuk mewujud kan kepemerintahan yang baik (good governance). Salah satu peran strategis 
aparatur pemerintah dalam mewujudkan kepemerintahan yang baik itu salah satunya adalah memberikan pelayanan prima kepada masyarakat, dengan demikian setiap aparatur pemerintah wajib melayani kepentingan masyarakat meliputi kemudahan untuk dihubungi dan ditemui. Kemudahan mendapatkan pelayanan, yang berkaitan dengan banyaknya outlet, petugas yang melayani, dan fasilitas pendukung lainnya.

Pemerintah kecamatan sangat berusaha keras dalam memenuhi kebutuhan masyarakat, misalnya mereka sealalu mempersiapkan tempat di kantor kecamatan sehari sebelum kegiatan dilakukan dan selalu membersihkan ketika kegiatan selesai agar bersih dan siap digunakan kembali di esok harinya. Mereka sigap dalam melihat dan memenuhi tuntutan masyarakat yang sedang melakukan proses pembuatan e-KTP, misalnya ketika antrian kekurangan kursi para aparat di kecamatan selalu menambah jumlah kursi agar masyarakat tidak ada yang berdiri selama proses antrian.

Aparat Kecamatan Kaledupa selalu berusaha yang terbaik untuk menjaga kenyamanan selama dalam proses pembuatan e-KTP tersebut.
Namun sayang hal ini tidak seimbang dengan produktivitas e-KTP yang jauh dibawah tingkat keberhasilan, sedangkan ini yang menjadi tujuan utama dari kegiatan ini. Hal ini sangat disayangkan karena pihak aparat kecamatan hanya menyediakan sarana dan prasarana saja untuk melakukan proses pembuatan e-KTP sedangkan orang yang mengambil data harus dari dinas Catatan Sipil dan yang memproduksi e-ktp tersebut adalah pemerintah pusat jadi patut dimaklumi karena pemerintah kecamatan tidak bisa berbuat banyak akan hal ini.

Pemerintah kecamatan sudah melakukan tanggung jawabnya dengan baik dalam proses penyediaan sarana dan prasarana dengan baik karena dilihat dari kepuasan dan respon positif dari masyarakat yang mengaku senang dalam pelayanan selama proses pengambilan data e-KTP, namun masih ada beberapa hal yang luput dari pengawasan aparat yaitu pada proses penyaluran e-KTP yang sudah selesai dimana pemerintah keamatan hanya menyalurkan begitu saja e-KTP yang sudah selesai tanpa mengingatkan kembali untuk pengaktivan e-KTP tersebut serta tidak menarik KTP yang lama sehingga para masyarakat 
memiliki 2 buah KTP. Hal ini tidak bisa dianggap remeh karena bisa menyababkan status kependudukan ganda serta kekacauan saat pendataan diwaktu Pilkada atau Pemilu dikemudian hari, bisa saja 1 orang memiliki 2 suara karena memiliki nama pemilih di 2 tempat berbeda jika KTP yang lama masih berlaku.

Sekalipun kemudian hingga triwulan pertama tahun 2015 di Kecamatan Kaledupa yang penulis himpun dari berbagai sumber, data capaian keberhasilan penyelesaian dan penyaluran e-KTP masih belum maksimal karena dari sekitar 6.212 orang yang memenuhi syarat umur eKTP, namun baru terdapat sekitar 3.391 e-KTP yang sudah tersalur sampai saat ini atau hanya sekitar 54,6 \% yang telah selesai dan tersalur di Masyarakat Kecamatan Kaledupa. Untuk itu, proses selanjutnya pengurusan e-KTP dilakukan pada Dinas Kependudukan dan Catatan Sipil Kabupaten Wakatobi.

Kinerja yang maksimal merupakan hal yang sangat dibutuhkan dalam penyelenggaraan dan pencapaian tujuan dari suatu organisasi. Jika dengan adanya kinerja yang berkualitas dari pegawai yang bekerja pada suatu organisasi, maka suda pasti organisasi itu akan dinilai telah menunjukkan hasil kerja yang memuaskan. Berkaitan dengan pelaksanaan tugas dan tanggungjawab dari suatu instansi, dan hal ini adalah proses yang penulis temukan dalam penyelenggaran pelayanan pembuatan e-KTP di Kantor Kecamatan Kaledupa.

\section{Kesimpulan}

Berdasarkan hasil penelitian dalam artikel ini, maka dapat disimpulkan bahwa Peranan Aparat dalam Pelayanan e-KTP di Kantor Kecamatan Kaledupa berjalan dengan optimal, pelayanan dilakukan dengan baik, penyampaian informasi yang jelas hingga pemberian layanan lainnya berlansung dengan baik. Hal ini dapat diukur melalui peran aparat menurut indikator daya tanggap (responsivenees), Kehandalan (Reability), Kompetensi (competence), Jaminan (assurance), Empati (emphaty) dan Akses (access). Hanya saja sarana dan prasarana yang terbatas dan operator yang tidak seimbang dengan jumlah masyarakat yang akan dilayani seringkali membuat pelayanan menjadi lambat dan tidak efektif.

\section{Daftar Pustaka}




\section{A. Buku}

BPS Kabupaten Wakatobi, 2015. Kecamatan Kaledupa Dalam Angka Tahun 2015, Wakatobi : BPS Kabupaten Wakatobi.

Dwiyanto, Agus. 2002. Mewujudkan Good Governance Melalui Pelayanan Publik. Yogyakarta: Gadjah Mada Universitas Press.

Indihono, Dwiyanto. 2006. Reformasi "Birokrasi Amplop" Mungkinkah? Yogyakarta: Gaya Media.

Kurniawan, Agung. 2005, Transformasi Pelayanan Public. Yogyakarta:Pembaruan.

Lexy Maleong.2001. Metodologi Penelitian Kualitatif. Bandung: Remaja Rosda

Parya. Moenir. 2001. Manajemen Pelayanan Umum. Jakarta: Bumi Aksara.

Narbuko, Kholid. 2005. Metode Penelitian. Jakarta: Bumi Aksara.

Nasution. 2001. Metodologi Penelitian Naturalistik Kualitatif. Bandung: Tarsito.

Nawawi, Hadari. 2006. Metode Penelitian Bidang Sosial. Yogyakarta: Gadjah Mada University Press.

Pasolong, Harbani. 2007. Teori Administrasi Publik. Bandung: CV. Alfabeta.

Sinambela, Lijan Poltak. 2006. Reformasi Pelayanan Publik Teori Kebijakan dan Implementasi. Jakarta: PT Bumi Aksara.

Sugiono. 2004. Memahami Penelitian Kualitatif. Bandung: CV. Alfabeta.

B. Peraturan Perundang-Undangan Undang-Undang Nomor 25 Tahun 2009 Tentang Pelayanan Publik.
Undang-undang No. 23 Tahun 2006 tentang Administrasi Kependudukan.

PP No. 37 Tahun 2007 tentang pelaksanaan UU No.23 Tahun 2006 tentang Administrasi Kependudukan

PERPRES No 25 Tahun 2008 Tentang tatacara Persyaratan Pendaftaran Penduduk dan Pencatatan Sipil.

PERPRES No 26 Tahun 2009 Tentang Penerapan KTP Berbasis NIK Secara Nasional

PERPRES No 35 Tahun 2010 Tentang Perubahan Atas PERPRES No 26 Tahun 2009 Penerapan E-KTP Paling Lambat Tahun 2012. 